\title{
Isolation and Mapping of Escherichia coli K12 Mutants Defective in Phenylacetate Degradation
}

\author{
By RONALD A. COOPER, * DAVID C. N. JONES \\ AND SUZANNE PARROTT \\ Department of Biochemistry, University of Leicester, University Road, Leicester LEI 7RH, UK
}

(Received 17 April 1985; revised 5 June 1985)

Mutants of Escherichia coli $\mathrm{K} 12$ unable to grow on phenylacetate have been isolated and mapped. The mutations were located in the relatively 'silent' region of the $E$. coli $\mathrm{K} 12$ chromosome at min 30.4 on the genetic map, with the gene order rac pac-1 pac- 2 trg.

\section{INTRODUCTION}

Reports have appeared recently on the unexpected ability of Escherichia coli strains to grow on aromatic acids. The pathways for the catabolism of 4-hydroxyphenylacetate (Cooper \& Skinner, 1980) and 3-phenylpropionate (Burlinghame \& Chapman, 1983) have been described and they are identical to those previously reported for catabolism of these compounds by various soil bacteria (Dagley et al., 1965; Sparnins et al., 1974).

Studies on phenylacetate catabolism in certain Pseudomonas sp. implicated 3,4-dihydroxyphenylacetate dioxygenase (Kunita, 1955a) and 2,5-dihydroxyphenylacetate dioxygenase (Kunita, 1955b) in degradative pathways, but in an extensive study of various pseudomonads grown on phenylacetate neither of these ring-fission dioxygenases could be detected in significant amounts (P. J. Chapman, personal communication). Similarly, no ring-fission reaction involved in phenylacetate catabolism in $E$. coli has yet been found (R. A. Cooper, unpublished observations). It seems, therefore, that there is still uncertainty about the pathway for bacterial phenylacetate catabolism.

Accordingly we have sought to obtain information on phenylacetate catabolism by isolating phenylacetate-negative mutants of $E$. coli. Although the pathway is still unresolved the mutants themselves were of interest since the genes affected were located in a region of the E. coli $\mathrm{K} 12$ chromosome where very few genes have so far been identified. This report describes the partial characterization of the mutants and their genetic mapping.

\section{METHODS}

Bacterial strains and growth conditions. The E. coli strains used are listed in Table 1. Bacterial cultures were grown aerobically at $30^{\circ} \mathrm{C}$ in minimal medium 63 or Luria broth (Miller, 1972). Individual carbon sources were sterilized separately and added to give the indicated final concentrations. Liquid media were solidified as required by the incorporation of $1.6 \%(\mathrm{w} / \mathrm{v})$ Oxoid bacteriological agar.

Substrate oxidation. Washed cells were prepared and their oxidative abilities measured as described previously (Cooper \& Skinner, 1980).

Isolation of mutants. Cultures were treated in minimal salts medium 63 with ethyl methanesulphonate (EMS) as described by Miller (1972). Survivors were allowed to grow overnight at $30^{\circ} \mathrm{C}$ on glucose minimal medium and phenylacetate-negative mutants were isolated after a penicillin enrichment procedure (Miller, 1972).

Metabolism of radioactive phenylacetate. Washed cells from $100 \mathrm{ml}$ exponential phase culture $\left(\mathrm{OD}_{680} \approx 0 \cdot 55\right)$ were resuspended in $10 \mathrm{ml}$ of minimal medium 63 to give $\mathrm{OD}_{680} \approx 5$. A sample $(2 \mathrm{ml})$ was shaken at $30^{\circ} \mathrm{C}$ with $1 \cdot 25 \mu \mathrm{Ci}(46.3 \mathrm{kBq})$ phenyl[ $\left[-^{1+} \mathrm{C}\right]$ acetate and a final phenylacetate concentration of $0.5 \mathrm{~mm}$. Samples $(0 \cdot 2 \mathrm{ml})$ were removed at timed intervals into $0.8 \mathrm{ml}$ absolute ethanol and heated at $80^{\circ} \mathrm{C}$ for 5 min to extract soluble material. Debris was removed by centrifugation and supernatant $(0.15 \mathrm{ml})$ was spotted onto Whatman $3 \mathrm{MM}$ 
Table 1. Escherichia coli K12 strains and plasmids

\begin{tabular}{|c|c|}
\hline E. coli $\mathrm{K} 12$ & Genotype \\
\hline K 10 & $\mathrm{Hfr} C \operatorname{thi}(?)$ \\
\hline PA309 & $\begin{array}{l}\mathrm{F}^{-} \text {thi argHBCE his thr trp rpsL lac Y malA } x y l \text { ara mil gal } \\
\text { tonA }\end{array}$ \\
\hline HB235 & $\mathrm{F}^{-}$thr leu his eda rpsL lac ara $x y$ l tonA ts.x trg-2:: $\operatorname{Tn} 10$ \\
\hline PLK 901 & $\begin{array}{l}\mathrm{F}^{-} \text {his-5l pro-23 trp-30 thy } A \text { lac- } 28 \text { deoB or deoC rpsL101 } \\
\text { AmanA uidA } \lambda^{+} z c j-230:: \operatorname{Tn} 10\end{array}$ \\
\hline PLK 902 & As PLK 901 but $z d a-231:: \operatorname{Tn} 10$ replaces $z c j-230:: \operatorname{Tn} 10$ \\
\hline $\mathrm{CO} 160$ & As $\mathrm{K} 10$ but pac- 1 \\
\hline $\mathrm{CO} 6161$ & As $C O 160$ but $z d a-231:: \operatorname{Tn} 10$ \\
\hline $\mathrm{CO} 62$ & As $\mathrm{CO} 160$ but $s r l:: \operatorname{Tn} 10$ rec $A$ \\
\hline $\mathrm{CO} 164$ & As $\mathrm{K} 10$ but pac-2 \\
\hline COI65 & As CO164 but $z d a-231:: \operatorname{Tn} 10$ \\
\hline CO535 & As PA309 but his pac-1 \\
\hline $\begin{array}{l}\text { Plasmids } \\
F^{\prime} \text { kit } \\
\text { pJPB } 13 \dagger \\
\text { pBS } 1+\end{array}$ & \\
\hline
\end{tabular}

F. C. Neidhardt

R. H. Walmsley

G. L. Hazelbauer

P. L. Kuempel

P. L. Kuempel

EMS mutagenesis

Pl (PLK902) $\times$ CO160; Tcr

selection

$\mathrm{Pl}(\mathrm{srl}:: \mathrm{Tn} 10 \mathrm{rec} A) \times \mathrm{CO} 60 ; \mathrm{Tc}$

selection

EMS mutagenesis

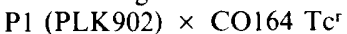

selection

$\mathrm{CO} 160 \times \mathrm{PA} 309 ; \mathrm{His}^{+}$selection

B. J. Bachmann

J. P. Bouché

J. P. Bouché

* B. J. Bachmann, E. coli Genetic Stock Center, Yale University, New Haven, Conn., USA; J. P. Bouché, C.R.B.G.C., C.N.R.S., Toulouse, France; G. L. Hazelbauer, Biochemistry/Biophysics Program, Washington State University, Pullman, Wash., USA ; P. L. Kuempel, Department of Molecular, Cellular and Developmental Biology, University of Colorado, Boulder, Colo., USA; F. C. Neidhardt, Department of Microbiology and Immunology, University of Michigan, Ann Arbor, Mich., USA; R. H. Walmsley, Department of Physics, University of Pennsylvania, Philadelphia, Pa., USA.

† pJPB13 is a derivative of pBR325 with the PstI fragment P41l, position 196-205 kb (Bouché, 1982).

$\ddagger \mathrm{pBS} 1$ is a derivative of pBR325 with the HindIII fragment H36b, position 204-214 kb (Béjar \& Bouché, 1983).

chromatography paper. Chromatograms were developed overnight in propan-2-ol/ammonia/water (Smith, 1960) and subjected to autoradiography. Incorporation into cells was measured in a similar system except that the samples $(0.2 \mathrm{ml})$ were filtered on nitrocellulose filters $(0.2 \mu \mathrm{m}$ pore size), washed rapidly on the filter with $5 \mathrm{ml}$ $0 \cdot 1 \mathrm{M}$-potassium phosphate buffer $\mathrm{pH} 7 \cdot 1$ and the filter plus cells transferred to a scintillation vial, containing $4 \mathrm{ml}$ of a dioxan-based scintillant, for counting.

Genetic procedures. Conjugal mating and phage Pl vir-mediated transduction were as described by Miller (1972). Cells were transformed by the method of Kushner (1978).

Chemicals. All chemicals used were the best grade commercially available. Phenyl[ $\left.1-1^{4} \mathrm{C}\right]$ acetate was from Amersham.

\section{RESULTS AND DISCUSSION}

\section{Partial characterization of mutants}

The mutants selected for study were affected specifically in phenylacetate catabolism and the gene symbol pac was chosen to describe them. On plates, they grew normally with glucose $(10 \mathrm{~mm})$, glycerol $(20 \mathrm{~mm})$, succinate $(15 \mathrm{~mm})$, acetate $(30 \mathrm{mM})$ and 3-phenylpropionate $(5 \mathrm{~mm})$ as sole carbon sources.

The ability to catabolize phenylacetate is inducible in $E$. coli $\mathrm{K} 12$. Wild-type cells grown in Luria broth or minimal medium with glucose, glycerol or succinate as sole carbon and energy source failed to oxidize phenylacetate. Cells induced by growth on Luria broth supplemented with $5 \mathrm{~mm}$-phenylacetate, or on $5 \mathrm{~mm}$-phenylacetate in minimal medium, readily oxidized phenylacetate.

To seek information on phenylacetate catabolism, the ability of mutant cells induced by growth on Luria broth supplemented with phenylacetate to metabolize phenyl[ $\left.1-{ }^{14} \mathrm{C}\right]$ acetate was monitored.

When mutant $\mathrm{CO} 64$ ( pac-2) was exposed to phenyl[ $\left[1{ }^{14} \mathrm{C}\right]$ acetate no radioactivity was incorporated into the cells and no radioactive compound other than phenylacetate was seen by chromatography. This suggested that $\mathrm{CO} 164$ was affected either in the uptake of phenylacetate 


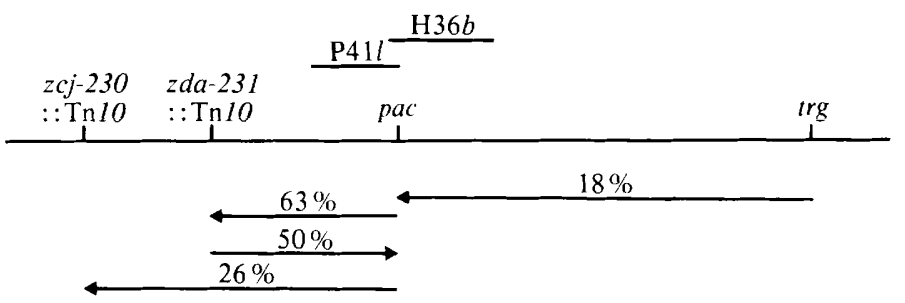

Fig. 1. Location of pac-l on the genetic map of Escherichia coli K12. An arrow head indicates the unselected marker in a co-transduction experiment. The chromosomal region and the cloned fragments are drawn to the same scale.

or in a regulatory gene controlling phenylacetate catabolism. In contrast, mutant $\mathrm{CO} 160$ ( pac-1) exposed to phenyl[ $\left[1-{ }^{14} \mathrm{C}\right]$ acetate did take up radioactivity and chromatographic analysis of the reaction mixtures showed that 2-hydroxyphenylacetate was produced. Under the experimental conditions employed all the phenylacetate could be converted to 2-hydroxyphenylacetate by this mutant.

To see if 2-hydroxyphenylacetate was an intermediate in phenylacetate degradation, wildtype cells grown on phenylacetate were exposed to 2-hydroxyphenylacetate. No significant oxidation of this compound was detected, so it seems either that 2-hydroxyphenylacetate is not a normal intermediate in phenylacetate catabolism or that it does not enter wild-type cells. However, these experiments showed that the mutants CO160 and CO164 were affected in different genes, so both were mapped to see whether the loci were linked.

\section{Mapping of mutations}

To obtain an approximate map position, the defective gene from $\mathrm{CO} 160$ was transferred by conjugation into strain PA309. After a $2 \mathrm{~h}$ period of mating streptomycin-resistant recombinants that had regained the ability to grow on glucose in the absence of either leucine, arginine or histidine were selected. When the recombinants were tested for growth on phenylacetate the $\mathrm{His}^{+}$recombinants showed the highest proportion of phenylacetate-negatives (about $30 \%$ ).

One such $\mathrm{F}^{-}$pac-1 strain, $\mathrm{CO} 535$, was then used as recipient in mating experiments with various $F$ prime-carrying strains (Low, 1972) to identify those which suppressed the pac-1 mutation. F123 from the Hfr B7 carrying the chromosome region min 25-30 and two much shorter F primes from the same Hfr, F618 and F619 (Bitner \& Kuempel, 1982), complemented the mutant phenotype indicating that the pac- 1 locus was around min $29-30$ on the E. coli $\mathrm{K} 12$ linkage map.

This region has very few known loci for co-transduction mapping, but a series of transposon insertions in this part of the chromosome have been identified (Binding et al., 1981; Fouts \& Barbour, 1982). Two insertions in the rac prophage, described by Binding et al. (1981), zcj$230:: \operatorname{Tn} 10$ (formerly $\operatorname{Tn} 10_{2}$ ) and $z d a-231:: \operatorname{Tn} 10$ (formerly $\operatorname{Tn} 10_{4}$ ), have been used to help locate pac-1.

P1 phage grown on PLK901 (zcj-230::Tn10) or PLK902 (zda-231::Tn10) were used to transduce mutant $\mathrm{CO} 160$ to $\mathrm{Pac}^{+}$. When the transductants were tested for tetracycline resistance there was $26 \%$ linkage (143/549) for PLK 901 and $63 \%$ linkage (137/216) for PLK 902. In a transduction using P1 grown on PLK 902 and CO160 as recipient, with selection for tetracycline resistance, $50 \%$ of the transductants $(26 / 52)$ became $\mathrm{Pac}^{+}$. A P1 lysate prepared on $\mathrm{CO} 161$ ( pac-1 zda-231::Tn 10) was used to transduce a wild-type strain to tetracycline resistance and $51 \%(26 / 51)$ of the transductants became $\mathrm{Pac}^{-}$.

These co-transduction frequencies were used to calculate genetic map distances $(\mathrm{Wu}, 1966)$, assuming that the effective length of the phage P1 transducing fragment is $2 \mathrm{~min}$. The pac-1 locus appeared to be $0.4 \mathrm{~min}$ from $z d a-231:: \operatorname{Tn} 10(\mathrm{~min} 30.0)$ and $0.7 \mathrm{~min}$ from $z c j-230:: \operatorname{Tn} 10$ (min 29.7) (Bitner \& Kuempel, 1981), indicating a location at min 30.4 on the E. coli K12 linkage map (Bachmann, 1983) (Fig. 1). No allowance for the size of the inserted Tn10 $(9 \cdot 3 \mathrm{~kb})$ has been made in these calculations. 
The proposed location for pac-1 indicates that it should be close to the $\operatorname{trg}$ locus at min 31.4 . When this was tested, using P1 phage grown on HB235 (trg-2:: $\mathrm{Tn} 10)$ and $\mathrm{CO} 160$ as recipient, $18 \%$ of the tetracycline resistant transductants became $\mathrm{Pac}^{+}(79 / 447)$. This suggests that pac-I and $\operatorname{trg}-2:: \operatorname{Tn} 10$ are 0.9 min apart on the genetic map.

It has been reported (Henson et al., 1984) that deletions extending from $\mathrm{trg}$ towards $\mathrm{rac}$ can be obtained easily and such deletions cause no detectable alteration of phenotype. We have taken HB235 and selected tetracycline-sensitive colonies by the fusaric acid method (Bochner et al., 1980). About $11 \%$ of the tetracycline-sensitive strains obtained were unable to grow on phenylacetate $(20 / 178)$.

The other pac mutant appeared to map in the same region as pac-1. Strain CO164 (pac-2) was transduced to tetracycline resistance using phage grown on PLK902 and only eight of 52 transductants remained phenylacetate-negative, indicating an $85 \%$ linkage between $p a c-2$ and $z d a-231:: \operatorname{Tn} 10$.

To obtain information on the order of the pac mutations, crosses were made between pairs of pac mutants with the $z d a-231:: \operatorname{Tn} 10$ of the donor as the selected outside marker. Some $\mathrm{Pac}^{+}$ progeny were obtained when CO165 (pac-2 zda-231::Tn10) was the donor with CO160 (pac-1) as the recipient (14/226). In the reverse cross with CO161 (pac-1 zda-231:: Tn 10) as donor and $\mathrm{CO} 164(p a c-2)$ as recipient, no $\mathrm{Pac}^{+}$transductants were obtained $(0 / 260)$.

In these three-factor crosses generation of $\mathrm{Pac}^{+}$requires two cross-overs or four cross-overs depending on the positions of the two mutant loci relative to the selected outside marker, $z d a$ $231:: \operatorname{Tn} 10$. When the mutant pac locus in the donor is proximal to $z d a-231:: \operatorname{Tn} 10$, four crossovers will be required to produce $\mathrm{Pac}^{+}$. When it is distal, $\mathrm{Pac}^{+}$can arise by two cross-overs. Since four cross-overs will occur significantly less frequently than two cross-overs the cross which produces the highest proportion of $\mathrm{Pac}^{+}$progeny will be that in which the pac locus of the donor is distal to the $z d a-231:: \operatorname{Tn} 10$ marker. The results suggest that of the mutants tested the pac- 1 mutation is closest to $z d a-231:: \operatorname{Tn} 10$.

The availability of cloned DNA from the region min 30-34 of the E. coli $\mathrm{K} 12$ chromosome (Béjar \& Bouché, 1983) made it possible to seek confirmation of the location of the pac genes. To do this two plasmids pBSI and pJPB13 were transformed into CO162 ( $\mathrm{pac}-1 \mathrm{rec} A$ ) to see if they complemented the mutant phenotype. Growth on phenylacetate was not restored by either plasmid. However, when $\mathrm{CO} 160\left(\mathrm{pac}-1 \mathrm{rec} \mathrm{A}^{+}\right)$was transformed with the plasmids and the transformants patched onto phenylacetate plates, large numbers of individual colonies appeared on each patch after 2-3d. The plasmid-free host strain gave no colonies on phenylacetate even after $10 \mathrm{~d}$. When the plasmids were transformed into CO164 (pac-2) and transformants tested on phenylacetate plates a similar phenomenon was seen except that only pBS1 gave rise to phenylacetate-positive colonies in this $\operatorname{rec} A^{+}$host.

It seems that either the whole or a part of the wild-type pac-1 gene is present on both plasmids but is either not expressed or does not give a functional protein. In the rec $A^{+}$strains repair of the defective gene can occur by recombination between the cloned DNA and the chromosome. Since the only cloned DNA common to both plasmids is that between $204 \mathrm{~kb}$ and $205 \mathrm{~kb}$ on the physical map of the region (Bouché, 1982) it seems that pac-1 is located around 204-205 kb. Since $\operatorname{trg}$ has been located at $247 \mathrm{~kb}$ (Bouché et al., 1982), the difference of $42 \mathrm{~kb}$ between pac- 1 and $\mathrm{trg}$ fits well with the map difference of 0.9 min estimated from the cotransduction studies, assuming there are $46 \mathrm{~kb}$ per min (Bouché et al., 1982). The precise position of the pac-2 mutation could not be established, but the apparent presence of the gene on pBS1 and its absence from pJPB13 is in accord with the gene order proposed.

Thus, at least two genes involved in phenylacetate catabolism are located in the region $\min 30.4$ of the E. coli $\mathrm{K} 12$ linkage map. This region was felt to be devoid of essential genes (Henson et al., 1984) and the suggestion that it may contain metabolically unusual or 'exotic' genes (Bachmann et al., 1976; Bouché et al., 1982) seems to be borne out by the experiments reported here.

We would like to thank B. J. Bachmann, P. L. Kuempel and G. L. Hazelbauer for providing bacterial strains and J. P. Bouché for supplying plasmids. D.C.N.J. was supported by an SERC postgraduate research studentship. 


\section{REFERENCES}

BaChmann, B. J. (1983). Linkage map of Escherichia coli K-12. Edition 7. Microbiological Reviews 47, 180 230.

BachmanN, B. J., Low, K. B. \& TAYLoR, A. L. (1976). Recalibrated linkage map of Escherichia coli K-12. Bacteriological Reviews 40, 116-167.

BÉJAR, S. \& BOUCHÉ, J. P. (1983). Molecular cloning of the terminus of Escherichia coli K-12 DNA replication. Journal of Bacteriology 153, 604-609.

Binding, R., Romansky, G., Bitner, R. \& Kuempel, P. (1981). Isolation and properties of Tn 10 insertions in the rac locus of Escherichia coli. Molecular and General Genetics 183, 333-340.

Bitner, R. M. \& Kuempel, P. (1981). Pl transduction map spanning the replication terminus of Escherichia coli K12. Molecular and General Genetics 184, 208212.

Bitner, R. M. \& Kuempel, P. L. (1982). P1 transduction mapping of the $\mathrm{trg}$ locus in $\mathrm{rac}^{+}$and $\mathrm{rac}$ strains of Escherichia coli K12. Journal of Bacteriologl 149 , 529-533.

Bochner, B. R., Huang, H. C., Schieven, G. L. \& AMES, B. N. (1980). Positive selection for loss of tetracycline resistance. Journal of Bacteriology 143, 926-933.

BouchÉ, J. P. (1982). Physical map of a $470 \times 10^{3}$ base-pair region flanking the terminus of DNA replication in the Escherichia coli $\mathrm{K} 12$ genome. Journal of Molecular Biology 154, 1-20.

Bouché, J. P., Gélugne, J. P., Louarn, J., Louarn, J. M. \& KAISER, K. (1982). Relationships between the physical and genetic maps of a $470 \times 10^{3}$ basepair region around the terminus of Escherichia coli K 12 DNA replication. Journal of Molecular Biology 154, $21-32$

Burlinghame, R. \& Chapman, P. J. (1983). Catabolism of phenylpropionic acid and its 3-hydroxy derivative by Escherichia coli. Journal of Bacteriolog. $155,113-121$.

CoOper, R. A. \& Skinner, M. A. (1980). Catabolism of
3- and 4-hydroxyphenylacetate by the 3,4-dihydroxyphenylacetate pathway in Escherichia coli. Journal of Bacteriology 143, 302-306.

Dagley, S., Chapman, P. J. \& Gibson, D. T. (1965). The metabolism of $\beta$-phenylpropionic acid by an Achromobacter. Biochemical Journal 97, 643-650.

Fouts, K. E. \& Barbour, S. D. (1982). Insertion of transposons through the major cotransduction gap of Escherichia coli K-12. Journal of Bacteriology 149, 106-113.

Henson, J. M., Kopp, B. \& Kuempel, P. L. (1984). Deletion of 60 kilobase pairs of DNA from the terC region of the chromosome of Escherichia coli. Molecular and General Genetics 193, 263-268.

Kunita, N. (1955a). Bacterial oxidation of phenylacetic acid. The pathway through homoprotocatechuic acid. Medical Journal of Osaka University 6, 697-702.

Kunita, N. (1955b). Bacterial oxidation of phenylacetic acid. The pathway through homogentisic acid. Medical Journal of Osaka University 6, 703-708.

KushNER, S. R. (1978). An improved method for transformation of Escherichia coli with ColE1derived plasmids. In Genetic Engineering, pp. 17-23. Edited by H. B. Boyer \& S. Nicosia. Amsterdam: Elsevier/North-Holland.

Low, K. B. (1972). Escherichia coli K-12 F-prime factors, old and new. Bacteriological Reviews 36, 587607.

Miller, J. H. (1972). Experiments in Molecular Genetics. Cold Spring Harbor. NY: Cold Spring Harbor Laboratory.

Smith, I. (1960). Chromatographic and Electrophoretic Techniques, vol. 1, pp. 291-307. Edited by I. Smith. London: Heinemann.

Sparnins, V. L., Chapman, P. J. \& Dagley, S. (1974). Bacterial degradation of 4-hydroxyphenylacetic acid and homoprotocatechuic acid. Journal of Bacteriology 120, 159-167.

WU, T. T. (1966). A model for three-point analysis of random general transduction. Genetics 54, 405-410. 